\title{
Pollyanna and the Grim Reaper
}

Toby Miller

Keywords: cell phones, melville, e-waste, media studies

https://doi.org/10.1525/001c.10772

Herman Melville's "The Paradise of Bachelors and the Tartarus of Maids" ${ }^{\text {finds }}$ the story's narrator in London. It's "the smiling month of May"2 1849 , and he's carousing with affluent unmarried lawyers who welcome him to their "band of brothers." Two years later, in a chilly New England mill where recycled cotton and linen are used to make paper, he encounters women workers preparing, pulping, pressing, and folding rags. Their faces are "pale with work, and blue with cold," their eyes "supernatural with unrelated misery." Speech is "banished from the spot."

The two groups are separated by time, space, gender, class, climate, labor, communication, and risk, the bachelors' fancy attire and healthy complexions worlds away from a toxic rag room where the "air swam with the fine, poisonous particles, which from all sides darted ... into the lungs." But the narrator connects the scenes and their actors. Realizing that London ragpickers regularly collected discarded clothing for export to US paper mills, he surmises that "among these heaps of rags there may be some old shirts, gathered from the dormitories of the Paradise of Bachelors" (Melville 1855).

Melville's juxtaposition of the perilous labor of print technology's women workers with the luxurious cloisters of the male ruling class has generated significant critical engagement (Serlin 1995; Thompson 2018). This remarkable work of short fiction alerts us to the media's two historic environmental roles: representation and materiality.

\section{REPRESENTATION}

"The Paradise of Bachelors and the Tartarus of Maids" lies within a long history of contradictory media representations of the environment (Boyce and Lewis 2009; Boykoff 2011; Brevini and Lewis 2018). Documentaries and news alternately boost the discourse of growth and note its unsustainability (Kaganovsky, MacKenzie, and Stenport 2019). Headlines focus on the arrival

\footnotetext{
* Toby Miller is Stuart Hall Professor of Cultural Studies at the Universidad Autónoma Metropolitana Unidad Cuajimalpa, in Mexico City. The author and editor of over forty books, his work has been translated into Spanish, Chinese, Portuguese, Japanese, Turkish, German, Italian, Farsi, and Swedish. Toby's most recent volumes are El trabajo cultural (2018), Greenwashing Culture (2018), Greenwashing Sport (2018), and The Routledge Companion to Global Cultural Policy (coedited, 2018). How Green is Your Smartphone? (co-authored) and The Persistence of Violence are in press. He is President of the Cultural Studies Association (US).

1 Thanks to the editors for inviting this piece and for their comments, and to Richard Maxwell for alerting me to this work and summarizing it so ably in other places.

2 No surprise it was "smiling." April 1849 had seen one of southern England's heaviest snowstorms, which cut off telegraphy, inter alia.
} 
or loss of capital investment in infrastructure and jobs and the deleterious impact on school pupils' health from nearby factories. Feature films and TV and radio dramas highlighting war, new technology, and futuristic visions of controlling nature offer both utopian and dystopian versions of where such scenarios may lead. Blockbusters emphasize bountiful technology gone mad, in the wrong hands, or contributing to climate change, with the James Bond franchise perhaps the most venerable exemplar. In sum, Pollyannaish and Grim Reaperish accounts of communications machinery transforming the environment are ever present.

\section{MATERIALITY}

Melville also captured the impact on occupational health of the media (in his case, paper). The corollary today is conflict-mining slavery obtaining natural resources for communications technologies and the labor process that assembles and recycles them (Al Jazeera 2019; Pun, Tse, and Ng 2019).

Consider the manufacture of analog television sets, which relied on exorbitant water use and numerous carcinogens. Cathode-ray tubes, made of zinc, copper, cesium, cadmium, silver, and lead, sent electrons into high-voltage electrodes that projected onto phosphorescent screens, emitting radiation as they did so. When these tubes were built and discarded, their components seeped into underground water, leaving heavy metals and toxic chemicals in their wake. The situation worsened with the transition to digital broadcasting (Maxwell and Miller 2012). Almost all TV-set manufacturing goes on in Mexico, Vietnam, and China, under hazardous circumstances, while recycling is done under dangerous circumstances in the Global South, generally in the informal economy, without labor or environmental protections (Miller 2012). If space allowed, similar stories could be told of cell phones, tablets, printers, and computers.

\section{RESISTANCE/RESPONSE}

When the iPad was launched outside the United States, protesters in Hong Kong ritually burned photographs of iPhones. Similar demonstrations have occurred in India, Mexico, and other offshore assembly and disassembly sites, and the 2018 Mobile World Congress was disrupted by activists. Numerous nongovernmental organizations record, research, publicize, and intervene in the labor and environmental horrors of media technology: the Centro de Reflexión y Acción Laboral/Center for Labor Reflection and Action, in Guadalajara; Berlin's Weltwirtschaft, Ökologie \& Entwicklung/World Economy, Ecology \& Development's Buy IT Fair campaign; 大學師生監察 無良企業行動/Students and Scholars Against Corporate Misbehavior based in Hong Kong; Manchester's Women in Informal Employment: Globalizing and Organizing; the Good Electronics Network of Amsterdam; Amnesty International's reporting; 中国劳工观察/China Labor Watch, in New York 
City; and the Basel Action Network, based in Seattle. The Global Alliance of Waste Pickers represents those who must deal with the detritus of abandoned electronics. ${ }^{3}$

\section{MEDIA STUDIES}

Environmental humanities and environmental communication have produced incisive ecocriticism. But they have done comparatively little work on media technologies' occupational health and safety aspects and their long, jagged history of pollution-however much Melville's fiction was ingested in high school and college! Most significant theory and research on these topics originates beyond the Global North-and beyond media studies (Srigboh et al. 2016; Ni et al. 2014). ${ }^{4}$ Nevertheless, there is both hope and precedent.

The history of technology, copyright, and regulation has always been important to media studies scholars, in contrast to their literary cousins. For example, film students learn about the advent of sound and the Paramount Decree, and communications majors understand the Federal Communications Commission and European Union privacy legislation. English and comparative literature undergrads, however, rarely encounter background information about how the texts they read are made, transported, or governed.

But media studies has neglected communications innovations as part of rapacious doctrines of economic growth designed to dominate the natural world. Henry Ford, eponym of the assembly line, argued that "unused forces of nature" must be "put into action ... to make them mankind's slaves" (1929, 71). Vannevar Bush, founding parent of the National Science Foundation, celebrated the drive to release humanity "from the bondage of bare existence" (1945). In the case of media technologies, the dominant mythology mixes the sublime-the awesome, the ineffable, the uncontrollable, the omnipotent - with the beautiful - the approachable, the attractive, the pliant, the soothing. They blend in a totemic, quasi-sacred quality that industrial societies ascribe to modern machinery, engineering, design, and marketing, as simultaneously powerful and pretty (Nye 1994).

Whether overtly or implicitly, research into technology within media studies has generally followed a Bazinian path: successive developments are presented as a march toward increased realism, driven by audience desires and/or corporate motives. But many of these innovations emerge from the state

\footnotetext{
3 http://www.fomento.org.mx/cereales/guadalajara.html; https://www.weed-online.org/themen/english.html; http://sacom.hk/; http://www.wiego.org/; https://goodelectronics.org/; https://www.amnesty.org/en/documents/afr62/3183/2016/en/)/; http://chinalaborwatch.org/home.aspx; https://www.ban.org/; https://www.taxjustice.net/; https://globalrec.org/es/.

4 These are simply indicative references. Scholars from Africa, Asia, and Latin America publish on related topics in science journals almost weekly.
} 
making war (Virilio 1989) and funding scholarship. Like the internet itself, donations to our daily digital lives have come from the militarized state and Research 1 schools.

Take the iPhone's click wheels, multitouch screens, global positioning systems, lithium-ion batteries, signal compression, hypertext markup language, liquidcrystal displays, Siri, cellular technology, and microprocessors. Apple has reason to thank the Defense Advanced Research Projects Agency, the European Organization for Nuclear Research, the Department of Energy, the CIA, the National Science Foundation, the US Navy, the Army Research Office, the National Institutes of Health, and the Department of Defense, which paid US and Western European universities to research and develop what became the smartphone's key aspects (Mazzucato 2015). Nothing to do with spectators, entrepreneurs, or corporations; everything to do with military interests funding scholars, then handing over the results to capital.

There are exceptions to media studies' neglect of labor and the environment in the creation and later life of commodity signs. ${ }^{5}$ And our professional associations have begun to address their own complicity in climate change. ${ }^{6}$ But the core topics are not required elements of omnibus curricula, general anthologies, media theorization, or synoptic textbooks.

That needs to change. We must rewire media studies to highlight the travails of labor and the impact of communications on the environment.

Cultural technologies are constantly attenuating and accreting meaning and materiality as they move from mines, smelters, factories, and warehouses to studios, homes, offices, and waste dumps. We should therefore follow these "things themselves, for their meanings are inscribed in their forms, their uses, their trajectories" (Appadurai 1986, 5). Such a line of inquiry is in keeping with the foremost historian of media technologies, Roger Chartier (1994), and their principal phenomenologist, Horst Ruthrof (1992). Blending such perspectives can develop affinities with workers on hitherto-hidden circuits of materials, manufacturing, distribution, production, reception, and disposal.

In short, the media should be understood in terms of their impact on the environment, not just their representation of it. Those professing media studies need to concentrate more on their fellow workers and citizens, whether they govern, create, consume, trash, or recycle the gadgets we love so much, know

\footnotetext{
5 They include Qiu 2016; Rust et al. 2016; Gabrys 2013; Winston 1998; Maxwell et al. 2014; Maxwell 2015; Rauch 2018; Starosielski and Walker 2016; Parikka 2015; and Bozak 2011.

6 See https://www.cmstudies.org/page/comm_environmental; https://iamcr.org/governance/committees; and https://www.icahdq.org/page/ Committees TF. I was asked to form such bodies for two associations. In each case, I was warned not to discuss putting an end to conferences that necessitated significant air travel or mount critiques of media technologies per se.
} 
so little about, and discard so cavalierly. Pollyanna must meet the Grim Reaper and side with those caught in media technology's perils-from the maids of Tartarus to their contemporary counterparts (Miller 2017). 


\section{REFERENCES}

Al Jazeera. 2019. “Conflicted: The Fight Over Congo’s Minerals.” March 3, 2019. https://www.aljazeera.com/programmes/faultlines/2015/11/conflicted-fight-congominerals-151118084541495.html.

Appadurai, Arjun. 1986. "Introduction: Commodities and the Politics of Value." In The Social Life of Things: Commodities in Cultural Perspective, edited by Arjun Appadurai, 5-63. New York: Cambridge University Press.

Boyce, Tammy, and Justin Lewis, eds. 2009. Climate Change and the Media. New York: Peter Lang.

Boykoff, Maxwell T. 2011. Who Speaks for the Climate?: Making Sense of Media Reporting on Climate Change. Cambridge: Cambridge University Press.

Bozak, Nadia. 2011. The Cinematic Footprint: Lights, Camera, Natural Resources. New Brunswick, NJ: Rutgers University Press.

Brevini, Benedetta, and Justin Lewis, eds. 2018. Climate Change and the Media. Vol. 2. New York: Peter Lang.

Bush, Vannevar. 1945. “As We May Think.” Atlantic Monthly, July 1945.

Chartier, Roger. 1994. The Order of Books: Readers, Authors, and Libraries in Europe between the Fourteenth and Eighteenth Centuries. Translated by L.G. Cochrane. Stanford: Stanford University Press.

Ford, Henry. 1929. My Philosophy of Industry: An Authorized Interview by Ray Leone Faurote. New York: Coward-McCann.

Gabrys, Jennifer. 2013. Digital Rubbish: A Natural History of Electronics. Ann Arbor: University of Michigan Press.

Kaganovsky, Lilya, Scott MacKenzie, and Anna Westerstahl Stenport, eds. 2019. Arctic Cinemas and the Documentary Ethos. Bloomington: Indiana University Press.

Maxwell, Richard, ed. 2015. The Routledge Companion to Labor and Media. New York: Routledge.

Maxwell, Richard, and Toby Miller. 2012. Greening the Media. New York: Oxford University Press.

Maxwell, Richard, Jon Raundalen, and Nina Lager Vestberg, eds. 2014. Media and the Ecological Crisis. New York: Routledge.

Mazzucato, Mariana. 2015. The Entrepreneurial State: Debunking Public vs. Private Sector Myths. New York: Public Affairs.

Melville, Herman. 1855. "The Paradise of Bachelors and the Tartarus of Maids." Harper's New Monthly Magazine 10: 670-78. https://resources.saylor.org/wwwresources/archived/site/wpcontent/uploads/2011/11/SAYLOR-ENGL405-5.2-PARADISE.pdf.

Miller, Toby. 2012. “The Ragpicker-Citizen.” In Border Rhetorics: Citizenship and Identity on the US-Mexican Frontier, edited by D. Robert DeChaine, 213-26. Tuscaloosa: University of Alabama Press. 
- - - 2017. "The Price of the Popular Media Is Paid by the Effluent Citizen." In Disability Media Studies, edited by Elizabeth Ellcessor and Bill Kirkpatrick, 295-310. New York: New York University Press.

$\mathrm{Ni}$, Wenqing, Yaowen Chen, Yue Huang, Xiaoling Wang, Gairong Zhang, Jiayi Luo, and Kusheng Wu. 2014. "Hair Mercury Concentrations and Associated Factors in an Electronic Waste Recycling Area, Guiyu, China.” Environmental Research 128 (January): 84-91. https://doi.org/10.1016/ j.envres.2013.10.005.

Nye, David E. 1994. American Technological Sublime. Cambridge, Mass: MIT Press.

Parikka, Jussi. 2015. A Geology of Media. Minneapolis: University of Minnesota Press.

Pun, Ngai, Tommy Tse, and Kenneth Ng. 2019. "Challenging Digital Capitalism: SACOM’s Campaigns against Apple and Foxconn as Monopoly Capital." Information, Communication $\sigma$ Society 22 (9): 1253-68. https://doi.org/10.1080/1369118x.2017.1414290.

Qiu, Jack L. 2016. Goodbye ISlave: A Manifesto for Digital Abolition. Urbana: University of Illinois Press.

Rauch, Jennifer. 2018. Slow Media: Why “Slow” Is Satisfying, Sustainable, and Smart. New York: Oxford University Press.

Rust, Stephen, Salma Monani, and Sean Cubitt, eds. 2016. Ecomedia: Key Issues. Abingdon, UK: Routledge.

Ruthrof, Horst. 1992. Pandora and Occam: On the Limits of Language and Literature. Bloomington: Indiana University Press.

Serlin, David Harley. 1995. "The Dialogue of Gender in Melville's 'The Paradise of Bachelors and the Tartarus of Maids.” Modern Language Studies 25 (2): 80-87. https://doi.org/10.2307/ $\underline{3195291 .}$.

Srigboh, Roland Kofi, Niladri Basu, Judith Stephens, Emmanuel Asampong, Marie Perkins, Richard L. Neitzel, and Julius Fobil. 2016. "Multiple Elemental Exposures Amongst Workers at the Agbogbloshie Electronic Waste (E-Waste) Site in Ghana.” Chemosphere 164 (December): 68-74. https://doi.org/10.1016/j.chemosphere.2016.08.089.

Starosielski, Nicole, and Janet Walker, eds. 2016. Sustainable Media: Critical Approaches to Media and Environment. New York: Routledge.

Thompson, Graham. 2018. Herman Melville Among the Magazines. Amherst: University of Massachusetts Press.

Virilio, Paul. 1989. War and Cinema: The Logistics of Perception. Translated by Patrick Cammiler. London: Verso.

Winston, Brian. 1998. Media Technology and Society: A History: From the Telegraph to the Internet. London: Routledge. 